\title{
CURRENT RANGE CHARACTERISTICS OF SWISS STONE PINE (PINUS CEMBRA L.) ALONG THE CARPATHIANS REVEALED BY CHLOROPLAST SSR MARKERS
}

\author{
MÁria HöHn, ${ }^{1 *}$ L. HufNAGel ${ }^{1}$, Klára CseKe ${ }^{2}$ and G. G. Vendramin ${ }^{3}$ \\ ${ }^{1}$ Corvinus University of Budapest, Faculty of Horticultural Sciences, \\ H-1118 Budapest, Ménesi street 44. \\ ${ }^{2}$ Hungarian Forest Research Institute, H-9600 Sárvár, Várkerület 30/A \\ ${ }^{3}$ CNR, Istituto di Genetica Vegetale, Via Madonna del Piano, 50019 Sesto Fiorentino (Firenze), Italy
}

(Received: August 2, 2010; accepted: October 14, 2010)

\begin{abstract}
We investigated the diversity pattern of nine Swiss stone pine (Pinus cembra L.) populations along the Carpathian range including the High Tatras, by using six chloroplast DNA microsatellites (cpSSR). Our aim was to detect genetically distinct regions by clustering of populations, and to tackle possible historical colonization routes. Our analysis referred to an investigated geographical range with the two most distant populations situated at about 500 air $\mathrm{km}$. We found that the most diverse populations are situated at the two edges of the investigated part, in the Retezat Mts. (South Carpathians) and the High Tatras, and diversity decreases towards the populations of the Eastern Carpathians. Hierarchical clustering and NMDS revealed that the populations of the South Carpathians with the Tatras form a distinct cluster, significantly separated from those of the Eastern Carpathians. Moreover, based on the most variable chloroplast microsatellites, the four populations of the two range edges are not significantly different. Our results, supported also by palynological and late glacial macrofossil evidences, indicate refugial territories within the Retezat Mts. that conserved rich haplotype composition. From this refugial territory Pinus cembra might have colonized the Eastern Carpathians, and this was accompanied by a gradual decrease in population diversity. Populations of the High Tatras might have had the same role in the colonizing events of the Carpathians, as positive correlation was detected among populations lying from each other at a distance of $280 \mathrm{~km}$, the maximum distance between neighbouring populations.
\end{abstract}

Keywords: Carpathians - chloroplast microsatellites - colonization route - Pinus cembra

\section{INTRODUCTION}

Glacial refugia of tree species and their post-glacial migration routes along the present distribution range may be revealed by fossil records and by detecting the degree of genetic divergence among populations. Postglacial range formations are mainly affected by the recolonization routes. It is also largely accepted that founder events towards the edge of a species' range cause the gradual decrease of the population genetic diversity $[17,6]$. Finally, the genetic parameters of the existing populations are determined by biogeographical characteristics, gene flow and effective populations size $[3,13]$.

\footnotetext{
*Corresponding author; e-mail: maria.hohn@uni-corvinus.hu
} 
Swiss stone pine (Pinus cembra) is a glacial relict species of the European high mountains, the Alps and the Carpathians [14]. Native populations preserved in the Carpathians and the Tatras have a highly disjunct distribution. The populations are restricted to the timberline ecotones forming mixed stands, mainly with spruce (Picea abies), larch (Larix decidua) or mountain pine (Pinus mugo) depending on the altitudinal gradient [1].

Recent studies, based either on izozymes [16, 2] or molecular DNA markers [9], concluded that high genetic diversity of the populations was preserved in the Carpathians despite small population size and isolation. Moreover, our former results based on three paternally inherited chloroplast microsatellite markers (cpSSR) have shown higher genetic variation in the Carpathians compared to the Central Alps. In some cases, population divergence expressed by fixation index $\left(\mathrm{F}_{\mathrm{st}}\right)$ have shown higher values among Carpathian populations; on the other hand no correlation was found between geographical and genetic distance within the Carpathian range. BARRIER analysis revealed the strongest separation in the eastern part of the European range, the Rodnei Mountains [9].

Fossil pollen, retrieved from lake sediments and mires of the Retezat and Calimani mountains, suggest the presence of Pinus cembra from the late glacial to the early Holocene at elevations up to $1900 \mathrm{~m}$. In the Retezat Mts., late glacial macrofossils indicate the existence of potential refugium for tree species like Larix and Pinus [12]. In turn, pollen diagrams from the Iezerul Calimani lake $(1650 \mathrm{~m})$ support the presence of $P$. cembra here just from the beginning of the late glacial [5].

Based on fossil evidences and the presumed existence of refugial territories for the European Swiss stone pine in the Carpathians, we hypothesize that this species followed more than one colonizing route from refugial territories along the high mountains ecotones of the Carpathians.

In addition to the formerly used three chloroplast SSR markers, three further ones were applied to test whether genetic structure and grouping of populations reveal specific spatial structure and to infer the possible historical colonization routes. Understanding the genetic patterns associated with geographical variation in populations may be useful for nature conservation decisions.

\section{MATERIALS AND METHODS}

\section{Study species}

Swiss stone pine (Pinus cembra L.) is a five needle pine of the subsection Cembrae subgenus Strobus [11]. It is wind pollinated and has nutritious, wingless seeds dispersed mainly by birds, especially by Nucifraga caryocatactes. The mutualistic relationship with this bird, which establishes seed caches in rock cracks, fundamentally determines the habitat quality of this pine species [10]. Pioneer individuals growing often on steep rocky slopes and screes are exposed to extreme habitat 
Table 1

Locations and sample size (n) of the studied Pinus cembra populations

\begin{tabular}{|l|c|c|c|c|c|}
\hline \multicolumn{1}{|c|}{ Populations } & Label & Region & Country & $\begin{array}{c}\text { Coordinates } \\
\text { (long.lat. }\end{array}$ & $\mathrm{n}$ \\
\hline Morskie Oko & $\mathrm{L}$ & High Tatras & Poland & $49.20 ; 20.08$ & 18 \\
\hline Velka Studena Dolina & $\mathrm{Sz}$ & High Tatras & Slovakia & $49.17 ; 20.20$ & 27 \\
\hline Kedryn, Forest Reserve & $\mathrm{U}$ & Ukrainian Carpathians & Ukraine & $48.42 ; 24.00$ & 21 \\
\hline Borsa & $\mathrm{R}$ & $\begin{array}{c}\text { Rodnei Mts. Eastern } \\
\text { Carp. }\end{array}$ & Romania & $47.58 ; 24.63$ & 14 \\
\hline Neagra Sarului & $\mathrm{Su}$ & $\begin{array}{c}\text { Calimani Mts. } \\
\text { Eastern Carp. }\end{array}$ & Romania & $47.17 ; 25.28$ & 56 \\
\hline Negoiu & $\mathrm{K}$ & $\begin{array}{c}\text { Calimani Mts. } \\
\text { Eastern Carp. }\end{array}$ & Romania & $47.10 ; 25.20$ & 57 \\
\hline Cindrel & $\mathrm{C}$ & $\begin{array}{c}\text { Cindrel Mts. } \\
\text { South Carp. }\end{array}$ & Romania & $45.58 ; 23.80$ & 15 \\
\hline Gentiana & $\mathrm{Re}$ & $\begin{array}{c}\text { Retezat Mts. } \\
\text { South Carp. }\end{array}$ & Romania & $45.38 ; 22.87$ & 16 \\
\hline Gemenele & $\mathrm{Ret}$ & $\begin{array}{c}\text { Retezat Mts. } \\
\text { South Carp. }\end{array}$ & Romania & $45.37 ; 22.83$ & 20 \\
\hline
\end{tabular}

conditions. Young trees that fall over because of the thin soil layer may survive by forming a new trunk of a former branch. Hence the real age of these survivors cannot be estimated.

\section{Population sampling}

Our analysis included 173 individuals from 9 populations sampled along the Carpathians from the Polish Tatra to the south-eastern edge of the species' range, the Retezat Mts. (Table 1).

We amplified six mononucleotide cpDNA microsatellite loci (simple sequence repeats, cpSSRs (Pt15169, Pt26081, Pt30204, Pt36480, Pt63718, Pt87268), according to [18]. Polymerase chain reaction (PCR) was performed with a thermal profile as follows: $5 \mathrm{~min}$ at $95^{\circ} \mathrm{C}, 5 \mathrm{~min}$ at $80^{\circ} \mathrm{C}, 25$ cycles of $1 \mathrm{~min}$ at $94{ }^{\circ} \mathrm{C}, 1 \mathrm{~min}$ at $55^{\circ} \mathrm{C}$, $1 \mathrm{~min}$ at $72{ }^{\circ} \mathrm{C}$, and a final extension step at $72{ }^{\circ} \mathrm{C}$ for $8 \mathrm{~min}$. The fluorescently labelled PCR products were separated and fragment sizes were determined by a 96-capillary Megabace 1000 automatic sequencer with a 400-bp size standard (GE Healthcare, Chalfont St Giles, UK).

\section{Statistical analysis}

Genetic variation i.e. haplotypic diversity of population was estimated according to [15]; $H=(n / n-1)\left(1-\Sigma p_{i}^{2}\right)$, where $p$ refers to the haplotype frequencies, and $n$ to the number of individuals per population. AMOVA analysis was performed to test population differentiation by Arlequin 3.11 [4]. 
We used PAST program [7] for a correlation analysis to compare pairwise fixation indices $\left(\mathrm{F}_{\mathrm{st}}\right)$ and geographical distances between the populations. Finally, hierarchial classification was achieved by paired group clustering analysis, Manhattan metric, and Non-Metric Multidimensional Scaling (NMDS) was performed to test the clustering of populations along the range.

\section{RESULTS}

The six cpSSR gave a total of 77 haplotypes. One cpSSR (Pt36480) proved to be monomorphic along the Carpathians. The highest number of population specific haplotypes (12), was registered in Gemenele (Retezat Mts) and Neagra Sarului (Calimani Mts.). Haplotypic diversity values were the highest in the Retezat Mountains and the High Tatras (Table 2). AMOVA analysis indicated that $86 \%$ of the total genetic variation derived from within-population variability while the genetic divergence among populations, was low $\left(\mathrm{F}_{\mathrm{st}}=0.14\right)$.

Based on the five variable cpSSR, pairwise $F_{\text {st }}$ and geographical distances were compared, but no significant correlation was found regarding the whole studied distribution range. The geographical distance between the two most distant populations is about 500 air km, but this distance is actually even longer - around $800 \mathrm{~km} \mathrm{-}$, because of the topographical constitution of the Carpathians. While we could detect a significant correlation up to $280 \mathrm{~km}(\mathrm{r}=0.611, \mathrm{p}=0.02)$ by taking the "steppingstone" model [19], we analysed the genetic structure of populations according to the haplotypic variation, by performing a hierarchical classification. The paired group clustering analysis using Euclidean distance sorted the samples in two main groups. The size of the two main groups were characterized by the number of the sampled trees of the populations belonging to the respective clusters (Table 2). In case of four populations (two from the Retezat Mts. and two from the Tatras) the ratio of samples belonging to one group was higher than $50 \%$ while in the other cases this ratio was

Table 2

Haplotypic diversity $(\mathrm{H})$ of the studied Pinus cembra populations and population samples $(\mathrm{N})$ according to the paired group hierarchical clustering with the ratio of individuals grouped into the alternative cluster. (For the abbreviations see Table 1)

\begin{tabular}{|c|c|c|c|c|}
\hline Pop. & $\mathrm{He}$ & $\mathrm{N}=67$ & $\mathrm{~N}=173$ & Ratio \\
\hline $\mathrm{Re}$ & 0.47 & 13 & 3 & 4.330 \\
\hline $\mathrm{Sz}$ & 0.42 & 15 & 12 & 1.250 \\
\hline $\mathrm{Ret}$ & 0.40 & 8 & 12 & 0.660 \\
\hline $\mathrm{L}$ & 0.43 & 7 & 10 & 0.700 \\
\hline $\mathrm{C}$ & 0.25 & 4 & 11 & 0.360 \\
\hline $\mathrm{Su}$ & 0.29 & 14 & 42 & 0.330 \\
\hline $\mathrm{K}$ & 0.22 & 4 & 53 & 0.075 \\
\hline $\mathrm{R}$ & 0.21 & 0 & 14 & 0.000 \\
\hline $\mathrm{U}$ & 0.33 & 2 & 16 & 0.125 \\
\hline
\end{tabular}


lower. The difference between the two groups was significant. By considering the size variants of the most variable loci, we counted their relative proportion in each population. Based on this grouping, we have performed a paired group hierarchial clustering $(\mathrm{HC})$ by Manhattan metric and found that the above mentioned 4 populations, two
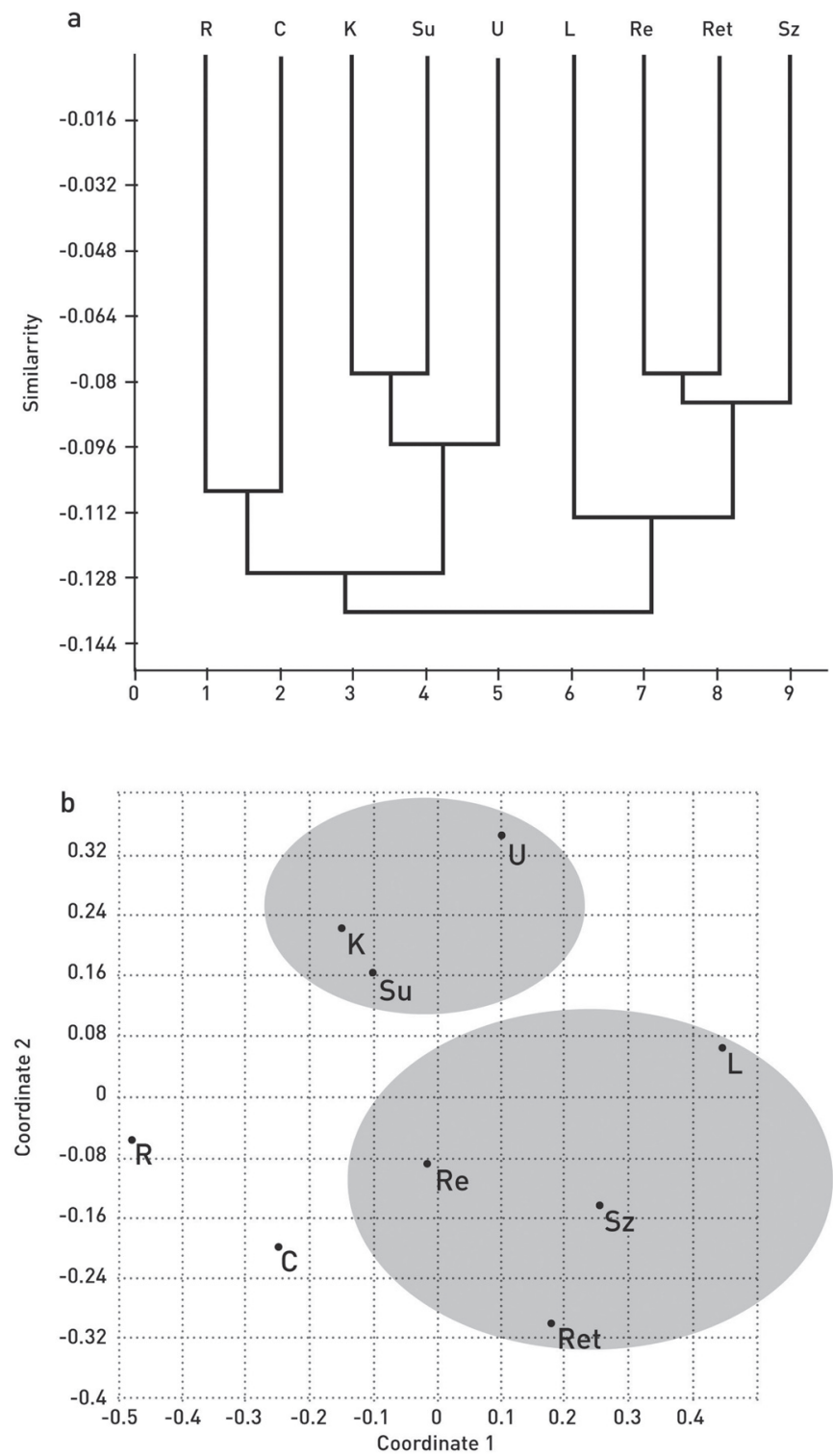

Fig. 1. Relationship between the populations of Pinus cembra according to hierarchial clustering (a) and NMDS (b) (Paired group - Manhattan metric) (For the abbreviations see Table 1) 
from the Tatras and two from the Retezat Mts., still form a distinct cluster (Fig. 1a). NMDS supported the results of the HC (Fig. 1b). In turn, based on the size variants of the two most variable loci (Pt15169, Pt30204), we generated four different combinations of the size variants. Then we counted the frequency of the four different types within the two main groups delineated by the cluster analysis. The two/four type frequency distribution was tested by two samples homogeneity, $\chi^{2}$ test. The distribution of the two groups differed significantly from each other. The distributions were then compared by a Shannon-t diversity test, what revealed that population diversity of the South-Carpathians, i.e. Retezat Mts. and the Tatras, is significantly higher than that of the Eastern Carpathians. Finally, we tested the frequency distribution of the Tatras and the South-Carpathians and found no significant differentiation. However, this value was higher for the Tatras $\left(\mathrm{H}_{\mathrm{Sh}}=1.2\right)$ and lower for the South-Carpathians $\left(\mathrm{H}_{\mathrm{Sh}}=0.9\right.$ psame $\left.=0.052\right)$.

\section{DISCUSSION}

According to our previous results [9], the six cpSSR markers confirmed the high population diversity of $P$. cembra along the Carpathians (Table 2). The overall Mantel test performed in [9] on populations of the European range, the Alps and the Carpathians, showed a low but positive correlation $(\mathrm{r}=0.286, \mathrm{P}<0.001)$, but could not detect any significant positive correlation between geographic and genetic distance along the populations of the Carpathians. In this study, by applying SAMOVA analysis also a fiable structuring of populations, was observed (data not shown). Nevertheless, a significant positive correlation could be detected among populations located at a distance up to $280 \mathrm{~km}$, the maximum distance between two neighbouring populations. By analysing the genetic structure of the populations within the investigated range, we found that the most diverse populations which are located at the two edges, in the Retezat Mts. and the Tatras, cluster together. Palynological and macrofossil evidences indicating late glacial refugial territories in the Retezat Mts. support the idea of conserving a rich haplotype composition. From this refugial territory, P.cembra might have colonized the Eastern Carpathians, which was accompanied by a gradual decrease in population diversity along the Eastern Carpathians. Populations of the High Tatras might have played the same role in the colonization of the Carpathians. On the meantime, when evaluating distribution of the genetic diversity along the studied range we have to count also on the population's life strategies, the strong selection pressure on the timberline, the limited gene flow and random effects, that can considerably influence present population variation and range characteristics [8]. Moreover, the Holocene reduction in the Carpathian stone pine area, caused by global climatic changes and the ever increasing anthropogenic impact at the same time, might be other factors generating the clustering of geographically distant populations, the Cindrel and the Rodnei Mts. 
REFERENCES

1. Blada, I. (2008) Pinus cembra distribution in the Romanian Carpathians. Ann. Forest Res. 51, 115132.

2. Belokon, M. M., Belokon, Yu. S., Politov, D. V., Altukhov, Yu. P. (2005) Allozyme polymorphism of Swiss stone pine Pinus cembra L. in mountain populations of the Alps and the Eastern Carpathians. Russ. J. Gen. 41, 1268-1280.

3. Eckert, C. G., Samis, K. E., Lougheed, S. C. (2008) Genetic variation across species' geographical ranges: the central-marginal hypothesis and beyond. Mol. Ecol. 17, 1170-1188.

4. Excoffier, L., Laval, G., Schneider, S. (2005) Arlequin ver. 3.0: An integrated software package for population genetics data analysis. Evol. Bioinf. Online 1, 47-50.

5. Farcas, S. (2008) Istoria vegetatiei tardiglaciare şi postglaciare din munții Calimani. Presa Universitara Clujeana, Cluj.

6. Gugerli, F., Rüegg, M., Vendramin, G. G. (2009) Gradual decline in genetic variability in Swiss stone pine populations (Pinus cembra L.) across Switzerland suggests postglacial re-colonization into the Alps from a common eastern glacial refugium. Botanica Helvetica 119, 13-22.

7. Hammer, R., Harper, D. A. T., Ryan, P. D. (2001) PAST: paleontological statistics software package for education and data analysis. Palaeontologia Electronica, 4, http://palaeo-electronica.org/2001_1/ past/past.pdf

8. Hamrick, J. L., Godt, J. W., Sherman-Broyles, S. L. (1992) Factors influencing levels of genetic diversity in woody plants. New Forest, 6, 95-124.

9. Höhn, M., Gugerli, F., Bisztray, Gy., Buonamici, A., Cseke, K., Hufnagel, L., Quintela-Sabaris, C., Sebastiani, F., Vendramin, G. G. (2009) Variation in the chloroplast DNA of Swiss stone pine (Pinus cembra L.) reflects contrasting post-glacial history of populations from the Carpathians and the Alps. Journal of Biogeography, 36, 1798-1806.

10. Linhart, Y. B., Tomback, D. F. (1985) Seed dispersal by nutcrackers causes multi-trunk growth form in pines. Oecologia 67, 107-110.

11. Liston, A., Robinson, W. A., Piñero, D., Alvarez-Buylla, E. R. (1999) Phylogenetics of Pinus (Pinaceae) based on nuclear ribosomal DNA internal transcribed spacer region sequences. Mol. Phyl. Evol. 11, 95-109.

12. Magyari, E., Jakab, G., Braun, M., Buczkó, K., Bálint, M. (2009) High resolution study of late glacial and early Holocene vegetation and tree line changes in the Southern Carpathian Mountains. Geophys. Res. Abstracts 11, 10549.

13. Mátyás, Cs. (2002) Erdészeti-természetvédelmi genetika (Forest and conservation genetics). Mezőgazda Kiadó, Budapest.

14. Meusel, H., Jager, E., Weinert, E. (1965) Vergleichende Chorologie der Zentraleuropaischen Flora. Gustav Fischer, Jena.

15. Nei, M. (1987) Molecular evolutionary genetics. Columbia University Press. New York.

16. Theodosiu, M., Parnuta, Gh. (2007) Genetic diversity and differentiation in Swiss stone pine (Pinus cembra L.) provenances from Romania. Analele ICAS 50, 7-15.

17. Tollefsrud, M. M., Kissling, R., Gugerli, F., Johnsen, Ø., Skroppa, T., Cheddadi, R., van der Knaap, P., Latalowa, M., Terhürne-Berson, R., Litt, T., Geburek, T., Brochmann, C., Sperisen, C. (2008) Genetic consequences of glacial survival and postglacial colonization in Norway spruce: combined analysis of mitochondrial DNA and fossil pollen. Mol. Ecol. 17, 4134-4150.

18. Vendramin, G. G., Lelli, L., Rossi, P., Morgante, M. (1996) A set of primers for the amplification of 20 chloroplast microsatellites in Pinaceae. Mol. Ecol. 5, 595-598.

19. White, T. L., Adams, W. T., Neale, D. B. (2007) Forest Genetics. CABI Publishing, Cambridge. 